\title{
PENGARUH MANAJEMEN RISIKO LIKUIDITAS TERHADAP KINERJA PERBANKAN DI BURSA EFEK INDONESIA
}

\author{
Herry Cornelius Hutabarat \\ Program Studi Akuntansi, Universitas Bunda Mulia, Jakarta, herry_hutabarat@yahoo.co.id
}

\begin{abstract}
ABSTRAK
Penelitian bertujuan menguji besar pengaruh manajemen risiko likuiditas terhadap Return on Asset/ROA dan terhadap Return on Equity/ROE. Manajemen risiko diproksikan dengan biaya operasional terhadap pendapatan operasional (BOPO), non performing loan (NPL), dan Reserve Requirement (RR). Hasil penelitian menunjukkan variable independen BOPO dan RR berpengaruh signifikan terhadap variabel dependen Y1, dan secara simultan variabel independen berpengaruh signifikan terhadap variabale dependen Y1 dan Y2.
\end{abstract}

Kata kunci : BOPO, NPL, RR, ROA dan ROE

\begin{abstract}
The study aims to examine the effect of liquidity risk management on Return on Assets / ROA and on Return on Equity / ROE. Risk management is proxies by operating costs on operating income (BOPO), non-performing loans (NPL), and Reserve Requirements $(\mathrm{RR})$. The results showed that the independent variables BOPO and RR had a significant effect on the dependent variable Y1, and simultaneously independent variables had a significant effect on the dependent variables Y1 and Y2.
\end{abstract}

Key words : BOPO, NPL, RR, ROA and ROE

\section{PENDAHULUAN}

Industri perbankan di Indonesia memegang peranan penting sebagai sumber pendanaan (sources of fund), disamping sumber pendanaan lainnya yaitu bursa efek (equity market). Pentingnya peranan perbankan di Indonesia dapat dilihat dari Statistik Perbankan di Indonesia yang diterbitkan oleh Otoritas Jasa Keuangan (OJK). Dari data terakhir yang diperoleh yaitu per 31 Juli 2015, diketahui jumlah bank konvensional yang beroperasi mencapai 119 bank dengan total aset senilai Rp. 5.926 triliun dimana jumlah ini hampir tiga kali lipat dibandingkan dengan Anggaran Pendapatan dan Belanja (APBN) Indonesia pada tahun yang sama, yaitu sebesar Rp. 2.039 triliun.

Indikator lain dari Statistik Perbankan Indonesia antara lain : kredit yang diberikan mencapai Rp. 3.868 trilun, ratio modal inti terhadap aktiva tertimbang menurut ratio (ATMR) dari rata-rata perbankan konvensional yang terdiri dari 119 bank, mencapai $18,21 \%$ jauh dari ketentuan minimal yang dipersyaratkan oleh regulator yaitu $8 \%$. 


\section{National Conference of Creative Industry: \\ Sustainable Tourism Industry for Economic Development}

Universitas Bunda Mulia, Jakarta, 5-6 September 2018

ISSN No: 2622 - 7436

Return on asset (ROA) mencapai $2,27 \%$, biaya operasional terhadap pendapatan operasional (BOPO) mencapai 115,84\%, Net Interest Income (NII) 5,32\%, Loan to Deposit Ratio (LDR) mencapai 88,50\%. Ratio aset likuid mencapai 17,03\% sedangkan aset produktif sebesar Rp. 5.071 triliun, aset lancar mencapai Rp. 4.747 trilun, dalam perhatian khusus (DPK) Rp. 213 triliun, kurang lancar 24 triliun, diragukan 16 triliun dan macet Rp. 71 triliun. Non Performing L oan (NPL) mencapai Rp. 111 triliun yang jauh dari angka standar 5\%. Giro wajib minimum (Reserve Requirement) diberlakuan sesuai Peraturan Bank Indonesia nomor 15/15/PBI/2013 tentang Giro Wajib Minimum Bank Umum dalam Rupiah dan Valuta Asing bagi Bank Umum Konvensional dan perubahannya. Untuk giro wajib minimum primer dalam Rupiah adalah $8 \%$ dari dana pihak ke tiga dan giro wajib sekuder dalam Rupiah sebesar $4 \%$ dari dana pihak ke tiga. Giro wajib minimum dalam valuta asing ditetapkan sebesar $8 \%$ dari dana pihak ke tiga dalam valuta asing.

Industri perbankan dalam melaksanakan kegiatannya erat dengan berbagai macam risiko. Risiko yang dimaksudkan sesuai dengan Peraturan Bank Indonesia (PBI) meliputi : risiko kredit, risiko pasar, risiko likuiditas, risiko operasional, risiko hukum, risiko stratejik, risiko kepatuhan dan risiko reputasi. Likuiditas sendiri dapat diartikan sebagai kemampuan bank memenuhi kewajibannya yang jatuh tempo tanpa mengalami kerugian. Risiko likuiditas merupakan suatu kondisi dimana bank tertentu tidak dapat memenuhi kewajibannya. Risiko likuiditas harus dikelola dengan baik dalam suatu manajemen risiko untuk menjaga tingkat profitabilitas bank yang diharapkan.

Manajemen risiko likuiditas yang efektif menjamin kemampuan bank dalam memenuhi kewajiban yang jatuh tempo dan mengurangi kemungkinan buruk yang dapat berkembang (Kumar dan Yadaf, 2013). Pengelolaan manajemen risiko likuiditas juga menjamin bank memiliki likuiditas sehingga bank dapat melanjutkan fungsinya (Vossenand Ness (2010).

Bermula dari kasus properti (Mortgage Case) di Amerika Serikat pada tahun 2008, terjadi krisis keuangan di Amerika Serikat yang merupakan krisis keuangan terbesar setelah depresi besar tahun 1930an, berakibat kelangkaan likuiditas pada bursa efek, sektor perbankan bentuk bisnis lainnya. Hal ini sebanarnya merupakan akibat dari manajemen risiko likuiditas yang tidak memadai.

Krisis keuangan lain yang mengakibatkan memburuknya bursa efek, langkanya likuiditas pasar antar bank, krisis utang luarnegeri terjadi di beberapa negara Eropa di awal tahun 2010 antara lain negara Yunani, Portugal, Irlandia, Italia dan Spanyol (Moro, 2013).

Kegagalan dari dua bank komersil di Lithuania disekitar tahun 2014 juga merupakan ketidakmampuan manajemen dalam mengelola risiko likuiditas atau tidak mampu mengelola likuiditasnya dengan baik (Erika Baraikaite et.al., 2014).

Manajemen risiko likuiditas yang baik dan berhasil yang dilaksanakan bank pada akhirnya juga dapat meningkatkan kinerja bank dan meningkatkan keuntungan, yang dapat tercermin dalam Return on Asset (ROA) dan Return on Equity (ROE) bank. 


\section{National Conference of Creative Industry: \\ Sustainable Tourism Industry for Economic Development}

Universitas Bunda Mulia, Jakarta, 5-6 September 2018

ISSN No: 2622 - 7436

\section{TINJAUAN PUSTAKA}

Dari kodifikasi Peraturan Bank Indonesia (PBI) dapat diketahui bahwa risiko adalah potensi kerugian akibat terjadinya suatu peristiwa (events) tertentu. Dengan demikian diperlukan suatu manajemen risiko untuk menanggulangi masalah ini. Selanjutnya dalam PBI tersebut dijelaskan bahwa manajemen risiko adalah serangkaian metodologi dan prosedur untuk mengidentifikasi, mengukur, memantau, dan mengendalikan risiko yang timbul dari seluruh kegiatan bank.

Risiko dalam PBI selanjutnya dibagi dalam : risiko kredit - adalah risiko akibat kegagalan debitur dan/atau pihak lain dalam memenuhi kewajiban kepada bank; risiko pasar - adalah risiko pada posisi neraca dan rekening administrative termasuk transaksi derivative, akibat perubahan secara keseluruhan dari kondisi pasar, termasuk perubahan harga option; risiko likuiditas - adalah risiko akibat ketidak mampuan bank untuk memenuhi kewajiban yang jatuh tempo dari sumber pendanaan arus kas dan/atau dari asset berlikuiditas tinggi yang dapat diagunkan, tanpa mengganggu aktivitas dan kondisi keuangan bank; risiko operasional - adalah risiko ketidakcukupan atau tidak berfungsinya proses internal, kesalahan manusia, kegagalan system, dan/atau adanya kejadian-kejadian yang mempengaruhi operasional bank; risiko hukum - adalah risiko akibat tuntutan hukum atau lemahnya aspek yuridis; risiko stratejik - adalah risiko akibat ketidaktepatan dalam pengambilan dan/atau pelaksanaan suatu keputusan stratejik, serta kegagalan dalam mengantisipasi perubahan lingkungan bisnis ; risiko kepatuhan adalah risiko akibat bank tidak mematuhi dan/atau tidak melaksanakan peraturan perundang-undangan dan ketentuan yang berlaku; risiko reputasi - adalah risiko akibat turunnya tingkat kepercayaan pemangku kepentingan (stakeholder) yang bersumber dari persepsi negative terhadap bank.

Likuiditas merupakan isntrumen yang menjadi faktor penting selama krisis keuangan belakangan ini. Ketidak pastian menyebakan pendanaan menguap, dan bank secara cepat mengalami kekuarangan kas untuk memenuhi kewajibannya yang jatuh tempo. Dalam berbagai kasus bank dibeberapa negara mengalami kegagalan dan terpaksa melakukan merger. Sebagai akibatnya untuk kepentingan stabilitas keuangan, likuiditas dalam jumlah yang besar disediakan oleh otoritas keuangan termasuk di Canada dan Amerika (Longworth, 2010; Bernanke 2008).

Hal lain yang menjadi masalah pokok dalam pengelolaan manajemen risiko bank antara lain adalah :

- Kecukupan Modal Minimum (Minimum Capital Requirements) Sesuai Basel I Capital Adequacy Ratio ( CAR) minimum bank $8 \%$ dari aktiva tertimbang menurut risiko. Perhitungan, bank dapat mempertimbangkan 3 hal berikut (1) The standardized approach (2) The foundation iternal ratings based (IRB) approach (3) The Advanced $I R B$ approach. Penghitungan untuk perbankan Indonesia dapat dilihat pada Peraturan Bank Indonesia. Regulator memberikan perhatian yang serius terhadap CAR dalam rangka stabilisasi system keuangan (Awdeh et al, 2011, Naceur dan Kandil, 2009). 


\section{National Conference of Creative Industry: \\ Sustainable Tourism Industry for Economic Development}

Universitas Bunda Mulia, Jakarta, 5-6 September 2018

ISSN No: 2622 - 7436

Naceur dan Kandil (2009) juga juga menemukan bahwa CAR mempengaruhi risiko terhadap kepemilikan dan meningkatkan ROA.

- $\quad$ Tingkat Suku Bunga Kredit Tingkat suku bunga kredit dihitung berdasarkan suku bunga dasar (prime lending rate) sesuai dengan jenis kredit yang diberikan. Suku bunga kredit perbankan Indonesia dihitung dengan memperhatikan ketentuan dari regulator (Bank Indonesia, Otoritas Jasa Keuangan, Lembaga Penjamin Simpanan).

- Cadangan Penghapusan Penyisihan Penghapusan Aktiva Produktif (PPAP) dihitung berdasarkan prosentase tertentu dari dihitung tingkat kolektibilitas kredit bank. Kolektibilitas kredit bank terdiri dari : lancar, dalam perhatian khusus, kurang lancar, diragukan dan macet. Kualitas kolektibilitas kredit akan mempengaruhi jumlah cadangan penghapusan penyisihan penghapusan aktiva produktif.

- Biaya Operasional terhadap Pendapatan Operasional (BOPO), merupakan ratio antara biaya operational Bank terhadap pendapatan operasional Bank. Berdasarkan Peraturan Bank Indonesi/PBI Nomor 14/26/PBI/2012 tentang Kegiatan Usaha dan Jaringan Kantor berdasarkan Modal Inti Bank; BOPO bagi bank umum kelompok usaha (BUKU) I maksimal 85\%, BUKU II kisaran 78\% - 80\%, BUKU III 70-75\% dan, BUKU IV 65\% $60 \%$

- Non Performing Loan (NPL) Non performing Loan (NPL) dihitung tingkat koletibilitas kredit bank : lancar, dalam perhatian khusus, kurang lancar, diragukan dan macet. Yang dimasukkan dalam kategori NPL adalah kolektibilitas : kurang lancar, diragukan dan macet. Penelitian yang dilakukan oleh Akhtar, 2007 menunjukkan banyak bank berfokus pada pinjaman korporasi, yang mengharuskan bank mempertahankan posisi likuiditas yang dipersyaratkan. Pinjaman ini kebanyakan merupakan pinjaman jangka panjang yang dapat menimbulkan problem likuiditas (Kashyap et al. 2002).

- Giro Wajib Minimum yang ditentukan oleh Bank Sentral. Kewajiban Bank untuk memelihara Giro Wajib Minimum (GWM), akan mempengaruhi likuiditas Bank. GWM adalah jumlah dana minimum yang wajib dipelihara oleh Bank yang besarnya ditetapkan oleh Bank Indonesia sebesar persentase tertentu dari DPK. GWM ini terdiri dari GWM Primer yang besarnya ditetapkan oleh Bank Indonesia sebesar persentase tertentu dari dari dana pihak ketiga, GWM sekunder yang merupakan cadangan minimum yang wajib dipelihara oleh Bank berupa Sertifikat Bank Indonesia, Sertifikat Deposito Bank Indonesia, Surat Berharga Negara dan/atau Excess Reserve, yang besarnya ditetapkan oleh Bank Indonesia sebesar persentase tertentu dari dana pihak ke tiga.

- Return on Asset (ROA) Penghitungan dari ROA : Laba bersih perusahaan dibagi dengan rata-rata total asset.

- Return on Equity (ROE) Penghitungan dari ROE: Laba bersih perusahaan setelah dikurangi dengan kewajiban saham preferen dibagi dengan rata-rata saham biasa beredar. 


\section{National Conference of Creative Industry: \\ Sustainable Tourism Industry for Economic Development}

Universitas Bunda Mulia, Jakarta, 5-6 September 2018

ISSN No: 2622 - 7436

Dari penelitian terdahulu dapat diuraikan beberapa hal sebagai berikut :

- Etienne Bordeleau dan Chirstoper Graham (2010) menyatakan bahwa likuiditas berpengaruh terhadap profitabilitas.

- Ahmed Arif, Ahmed Nauman Anees (2012) dari multiple regressions memperlihatkan bahwa risiko likuiditas mempengaruhi profitabilitas bank secara signifikan.

- Ogboi dan Unuafe (2013) yang meneliti pengaruh dari credit risk management dan capital adequacy menyimpulkan pengaruh kedua indikator tersebut terhadap kinerja keuangan adalah signifikan.

- Aruwa dan Musa (2012) yang meneliti pengaruh dari komponen-komponen dalam risk management mempunyai pengaruh signifikan terhadap kinerja keuangan.

- Poudel (2012), Musyoki dan Kadubo (2012) yang meneliti pengaruh dari risk management terhadap kinerja keuangan menyatakan bahwa default rate berpengaruh signifikan terhadap kinerja keuangan.

\section{METODE PENELITIAN}

Jenis hubungan dalam penelitian ini adalah hubungan asosiatif kausal yaitu hubungan sebab akibat dimana terdapat variabel bebas yang mempengaruhi dan variabel terikat yang dipengaruhi.

Menurut analisis dan jenis data, penelitian termasuk dalam penelitian kuantitatif, yaitu penelitian yang datanya dinyatakan dalam bentuk angka atau data kuantitatif yang diangkakan, atau penelitian yang dilakukan dengan cara mengumpulkan data yang ada hubungannya dengan judul penelitian penulis dan menganalisisnya dengan data yang diperoleh.

\section{Populasi}

Populasi adalah seluruh bank yang terdaftar di Bursa Efek Indonesia mulai tahun 2008 hingga 2016 ( 9 tahun). Jumlah populasi: 45 bank.

\section{Sample}

Sampel penelitian dipilih dengan pertimbangan terdaftar di Bursa Efek Indonesia (BEI) paling sedikit 4 tahun, tujuannya untuk meningkatkan kualitas hasil penelitian dan mencapai kesimpulan yang layak digeneralisasikan (signifikan). Jumlah sampel: 24 bank.

Kriteria sampel adalah sebagai berikut :

1) Perusahaan jasa perbankan yang terdaftar di Bursa Efek Indonesia sampai dengan tahun 2016.

2) Perusahaan yang membayar dividen dalam 3 tahun terakhir.

3) Tidak mendapat peringatan dari Otoritas Jasa Keuangan 
4) Menerbitkan laporan keuangan tahunan sesuai dengan ketentuan Otoritas Jasa Keuangan.

\section{Pengembangan Instrumen}

Objek yang diteliti terdiri dari dua variabel yaitu variabel bebas (independen) dan variabel terikat (dependen). Variabel bebas yaitu kecukupan modal, non performing loan, biaya operasional terhadap pendapatan operasional, cadangan kerugian dan giro wajib minimum; variabel-variabel tersebut diproksikan sebagai X1, X2, X3; sedangkan yang menjadi variabel terikat adalah Return on Asset/ROA dan Return on Equity/ROE dan diproksikan sebagai Y1 dan Y2.

Subyek penelitian adalah perusahaan jasa perbankan yang terdaftar di Bursa Efek Indonesia periode 2008-2016. Berdasarkan objek dan subjek peneltian tersebut, maka akan diteliti bagaimana pengaruh manajemen risiko likuiditas terhadap kinerja bank.

Secara ringkas, instrument penelitian dapat diuraikan sebagai berikut;

\begin{tabular}{|l|l|l|}
\hline Ringkasan & Deskripsi & $\begin{array}{l}\text { Pengukuran } \\
\text { (Ratio) }\end{array}$ \\
\hline $\begin{array}{l}\text { X1 } \\
\text { (BOPO) }\end{array}$ & Operational Cost/Revenue & $\begin{array}{l}\text { Percentage of } \\
\text { Operational } \\
\text { Cost/Revenue }\end{array}$ \\
\hline X2(NPL) & $\begin{array}{l}\text { The level of Non } \\
\text { Performing Loans }\end{array}$ & $\begin{array}{l}\text { Non Performing } \\
\text { Loans/Gross Loans } \\
\text { and Advances }\end{array}$ \\
\hline X3 (RR) & Reserve Requirement & $\begin{array}{l}\text { Percentage of } \\
\text { Reserve } \\
\text { Requirement }\end{array}$ \\
\hline Y1 (ROA) & Return on Asset & $\begin{array}{l}\text { Net Income/Total } \\
\text { Assets }\end{array}$ \\
\hline Y2 (ROE) & Return on Equity & $\begin{array}{l}\text { Net Income/Total } \\
\text { Equity }\end{array}$ \\
\hline
\end{tabular}

\section{Sumber: hasil pengolahan}

\section{Catatan :}

Nilai X1,X2,X3, Y1,Y2 merupakan nilai rata-rata dari 24 bank sampel.

\section{Hipotesis}

Ho : Manajemen risiko likuiditas tidak berpengaruh terhadap kinerja perbankan

Ha : Manajemen risiko likuiditas berpengaruh terhadap kinerja perbankan 


\title{
National Conference of Creative Industry: \\ Sustainable Tourism Industry for Economic Development
}

Universitas Bunda Mulia, Jakarta, 5-6 September 2018

ISSN No: 2622 - 7436

\author{
Subset hipotesis \\ Ha1 : BOPO berpengaruh kepada ROA, ROE \\ $\mathrm{Ha} 2$ : NPL berpengaruh kepada ROA, ROE \\ Ha3 : RR berpengaruh kepada ROA, ROE \\ Ha4 : BOPO, NPL, RR secara simultan berpengaruh terhadap ROA,ROE
}

Objek yang diteliti terdiri dari dua variabel yaitu variabel bebas (independen) dan variabel terikat (dependen). Variabel bebas terdiri dari : non performing loan, biaya operasional terhadap pendapatan operasional (BOPO), giro wajib minimum (reserve requirement/RR); variabel-variabel tersebut diproksikan sebagai $\mathrm{X} 1, \mathrm{X} 2, \mathrm{X} 3$, ; sedangkan yang menjadi variabel terikat adalah Return on Asset/ROA dan Return on Equity/ROE dan diproksikan sebagai Y1 dan Y2.

Subyek penelitian adalah perusahaan jasa perbankan yang terdaftar di Bursa Efek Indonesia periode 2008-2016. Berdasarkan objek dan subjek peneltian tersebut, maka akan diteliti bagaimana pengaruh manajemen risiko likuiditas terhadap kinerja bank.

\section{Teknik Analisis Data}

Analisis data dilakukan dengan menggunakan analisi kuantitatif dengan perhitungan statistik. Media yang digunakan adalah Microsoft Excel dan program SPSS 24.

\section{1) Uji kualitas data}

\section{a. Statistik Deskriptif}

Statistik deskriptif adalah statistik yang digunakan menganalisa data dengan cara mendeskripsikan atau menggambarkan data yang telah terkumpul sebagimana adanya tanpa bermaksud atau membuat kesimpulan yang berlaku umum atau generalisasi. Termasuk dalam statistik deskriptif antara lain adalah penyajian data melalui mean, median, modus dan lain-lain.

\section{b. Uji Normalitas data}

Menguji apakah dalam suatu model regresi, variabel dependen dan variabel independen, keduanya mempunyai hubungan distribusi normal atau tidak. Model regresi yang baik adalah memiliki distribusi normal atau mendekati normal.

Salah satu cara menguji normalitas adalah One Sample Kolmogorov Smirnov Test. Data dikatakan berdistribusi normal jika Asymp. Sig (2-tailed) > 0,05. Dan data dikatakan tidak berdistribusi normal jika Asymp. Sig (2-tailed) < 0,05 .

\section{c. Statistik Deskriptif}

Statistik deskriptif adalah statistik yang digunakan menganalisa data dengan cara mendeskripsikan atau menggambarkan data yang telah terkumpul sebagimana adanya tanpa bermaksud atau membuat kesimpulan yang berlaku umum atau generalisasi. Termasuk dalam statistik deskriptif antara lain adalah penyajian data melalui mean, median, modus dan lain-lain. 


\section{National Conference of Creative Industry: \\ Sustainable Tourism Industry for Economic Development}

Universitas Bunda Mulia, Jakarta, 5-6 September 2018

ISSN No: 2622 - 7436

2) Uji Asumsi Klasik

\section{a. Multikolineritas}

Dalam regresi linear harus dianggap tidak ada multikolineritas diantara variabel bebas, asumsi multikolinearitas disebabkan suatu keadaan dimana variael-variabel independen mempunyai korelasi yang tinggi antara satu dengan yang lainnya.

Kolinearitas secara statistik dapat diidentifikasi dengan menggunakan nilai collinearity statistiks-tolerance dan varian inflation factor (VIF). Tolerance memiliki rentang nilai dari 0 sampai 1 , jika nilainya kecil (mendekati), maka variabel tersebut merupakan kombinasi linear dari variabel independen yang lain yang berarti terjadi multikolinearitas. Dalam varian inflation factor (VIF), jika VIF yang dihasilkan diantara 1-10 maka tidak terjadi multikolinearitas.

\section{b. Autokorelasi}

Uji autokorelasi untuk mengetahui ada tidaknya korelasi antara variable penganggu pada periode tertentu dengan variabel sebelumnya. Mendeteksi autokorelasi dapat menggunakan nilai Durbin Watson dibandingkan dengan tabel Durbin Watson ( dL dan dU). Jika dU $<$ dL hitung $<4$-dU maka tidak terjadi autokorelasi.

\section{c. Heteroskedastisitas}

Uji heteroskedastisitas menguji terjadinya perbedaan variance residual suatu periode pengamatan ke periode pengamatan yang lain. Cara memprediksi ada tidaknya heterokedastisitas pada suatu model dapat dilihat pada pola gambar Scatterplot. Suatu regresi tidak terjadi heteroskedastisitas jika (1) titik titik data menyebar di atas dan dibawah atau disekitar angka nol (2) titik titik data tidak mengumpul hanya di atas atau dibawah saja (3) titik titik data tidak membentuk pola bergelombang melebar kemudian menyempit dan melebar kembali (4) penyebaran titik titik data tidak berpola.

Secara matematis $\sigma^{2}(\mathrm{cj})=\sigma^{2}(\mathrm{cj})=\sigma^{2}$ (homokedastisitas). Validitas dari asumsi ini telah ditunjukkan dalam regresi nilai mutlak residual pada variabel independen.

\section{3) Uji Regresi Berganda/Uji Signifikansi}

\section{a) Uji simultan}

Uji ini dilaksanakan untuk mengetahui pengaruh dari variable indepeden $\mathrm{X} 1$, $\mathrm{X} 2$,X3 secara bersama-sama baik terhadap variable dependen Y1 dan variable dependen $\mathrm{Y} 2$

b) Uji partial

Uji ini dilaksanakan untuk mengetahui pengaruh dari variable indepeden $\mathrm{X} 1, \mathrm{X} 2, \mathrm{X} 3$ secara sendiri-sendiri baik terhadap variable dependen $\mathrm{Y} 1$ dan variable dependen $\mathrm{Y} 2$ 


\section{HASIL PENELITIAN DAN PEMBAHASAN}

\section{Pengujian terhadap Y1 dengan Varibel independen NPL, RR, BOPO}

1. Pengujian secara parsial

\begin{tabular}{|c|c|c|c|c|c|c|c|c|}
\hline \multicolumn{9}{|c|}{ Coefficients $^{a}$} \\
\hline \multirow{2}{*}{\multicolumn{2}{|c|}{ Model }} & \multicolumn{2}{|c|}{$\begin{array}{l}\text { Unstandardized } \\
\text { Coefficients }\end{array}$} & \multirow{2}{*}{$\begin{array}{c}\text { Standardized } \\
\text { Coefficients } \\
\text { Beta }\end{array}$} & \multirow[b]{2}{*}{$t$} & \multirow[b]{2}{*}{ Sig. } & \multirow{2}{*}{$\begin{array}{l}\text { Collinearity } \\
\text { Tolerance }\end{array}$} & \multirow{2}{*}{$\begin{array}{l}\text { Statistics } \\
\text { VIF }\end{array}$} \\
\hline & & $\mathrm{B}$ & Std. Error & & & & & \\
\hline 1 & (Constant) & 5.784 & 1.572 & & 3.679 & .014 & & \\
\hline & $\overline{N P L}$ & -.108 & .175 & -.151 & -.614 & .566 & .155 & 6.447 \\
\hline & RR & .121 & .043 & .303 & 2.786 & .039 & .799 & 1.252 \\
\hline & BOPO & -.056 & .021 & -.661 & -2.618 & .047 & .148 & 6.752 \\
\hline
\end{tabular}

a. Dependent Variable: $\mathrm{Y} 1$

$\mathrm{Y} 1=5,784-108 \mathrm{NPL}+0,121 \mathrm{RR}-0,056 \mathrm{BOPO}+e$

Untuk NPL nilai Sig. 0,566 > dari 0,05 sehingga Ho1 diterima dan Ha1 ditolak yaitu pengaruh dari NPL tidak signifikan terhadap Y1.

Untuk RR nilai Sig. 0,039< dari 0,05 sehingga Ho2 ditolak dan $\mathrm{Ha} 2$ diterima yaitu ada pengaruh dari RR yang signifikan terhadap Y1

Untuk BOPO nilai Sig. 0,047 < 0,05 sehingga Ho3 ditolak dan Ha2 diterima yaitu ada pengaruh dari BOPO yang signifikan terhadap Y1

2. Pengujian secara simultan

\begin{tabular}{|c|c|c|c|c|c|c|}
\hline \multicolumn{7}{|c|}{ ANOVAa } \\
\hline & & Sum of Squares & Df & Mean Square & $\mathrm{F}$ & Sig. \\
\hline \multirow[t]{3}{*}{$\overline{1}$} & Regression & 1.370 & 3 & .457 & 33.617 & $.001^{b}$ \\
\hline & Residual & .068 & 5 & .014 & & \\
\hline & Total & 1.438 & 8 & & & \\
\hline
\end{tabular}

a. Dependent Variable: Y1

b. Predictors: (Constant), BOPO, RR, NPL

Pengujian secara simultan nilai Sig. 0,001 <0,05 sehingga Ha4 diterima dan Ho4 ditolak yaitu ada pengaruh signifikan dari dari BOPO, RR dan NPL terhadap Y1.

\begin{tabular}{|c|c|c|c|c|c|}
\hline \multicolumn{6}{|c|}{ Model Summary } \\
\hline Model & $\mathrm{R}$ & R Square & Adjusted R Square & $\begin{array}{l}\text { Std. Error of the } \\
\text { Estimate }\end{array}$ & Durbin-Watson \\
\hline 1 & $.976^{a}$ & .953 & .924 & .11654 & 2.991 \\
\hline
\end{tabular}

Dari uji determinasi diketahui nilai dari $\mathrm{R}$ Square adalah 0,953 yang berarti model regresi dipengaruhi 95,30\% oleh variabel BOPO, RR, NPL dan sisinya dipengaruhi oleh faktor lainnya yang tidak terdapat dalam model. 


\section{Pengujian terhadap Y2 dengan Varibel independen NPL, RR, BOPO}

1. Pengujian secara parsial

\begin{tabular}{|c|c|c|c|c|c|c|c|c|}
\hline \multicolumn{9}{|c|}{ Coefficients $^{a}$} \\
\hline \multirow{2}{*}{\multicolumn{2}{|c|}{ Model }} & \multicolumn{2}{|c|}{$\begin{array}{l}\text { Unstandardized } \\
\text { Coefficients }\end{array}$} & \multirow{2}{*}{$\begin{array}{c}\text { Standardized } \\
\text { Coefficients } \\
\text { Beta }\end{array}$} & \multirow[b]{2}{*}{$t$} & \multirow[b]{2}{*}{ Sig. } & \multirow{2}{*}{$\begin{array}{l}\text { Collinearity } \\
\text { Tolerance }\end{array}$} & \multirow{2}{*}{$\begin{array}{l}\text { Statistics } \\
\text { VIF }\end{array}$} \\
\hline & & B & Std. Error & & & & & \\
\hline 7 & (Constant) & 67.595 & 22.275 & & 3.035 & .029 & & \\
\hline & NPL & 1.624 & 2.482 & .277 & .654 & .542 & .155 & 6.447 \\
\hline & RR & .647 & .614 & .196 & 1.054 & .340 & .799 & 1.252 \\
\hline & BOPO & -.751 & .304 & -1.071 & -2.472 & .056 & .148 & 6.752 \\
\hline
\end{tabular}

a. Dependent Variable: Y2

$\mathrm{Y} 2=67,595+1,624 \mathrm{NPL}+0.647 \mathrm{RR}-0,751 \mathrm{BOPO}+e$

Untuk NPL nilai Sig. 0,542 > dari 0,05 sehingga Ho1 diterima dan Ha1 ditolak yaitu pengaruh dari NPL tidak signifikan terhadap Y2.

Untuk RR nilai Sig. 0,340 > dari 0,05 sehingga Ho2 diterima Ha2 ditolak yaitu pengaruh dari RR tidak signifikan terhadap Y2

Untuk BOPO nilai Sig. 0,56 < 0,05 sehingga Ho3 diterima dan $\mathrm{Ha} 2$ ditolak yaitu pengaruh dari BOPO tidak signifikan terhadap Y2

2. Pengujian secara simultan

\begin{tabular}{llr|r|r|r|r}
\multicolumn{7}{c}{ ANOVA $^{\text {Ma }}$} \\
& Sum of Squares & df & Mean Square & F & Sig. \\
\hline 1 & Regression & 84.517 & 3 & 28.172 & 10.335 & $.014^{\mathrm{b}}$ \\
\cline { 2 - 8 } & Residual & 13.629 & 5 & 2.726 & & \\
\cline { 2 - 8 } & Total & 98.147 & 8 & & & \\
\hline
\end{tabular}

a. Dependent Variable: Y2

b. Predictors: (Constant), BOPO, RR, NPL

Pengujian secara simultan nilai Sig. 0,014 < 0,05 sehingga Ha4 diterima dan Ho4 ditolak yaitu ada pengaruh signifikan dari dari BOPO, RR dan NPL terhadap Y2.

3. Uji determinasi

\begin{tabular}{|c|c|c|c|c|c|}
\hline \multicolumn{6}{|c|}{ Model Summary } \\
\hline Model & $\mathrm{R}$ & R Square & $\begin{array}{l}\text { Adjusted R } \\
\text { Square }\end{array}$ & $\begin{array}{c}\text { Std. Error of the } \\
\text { Estimate }\end{array}$ & Durbin-Watson \\
\hline 1 & $.928^{a}$ & .861 & .778 & 1.65101 & 1.467 \\
\hline
\end{tabular}


a. Predictors: (Constant), BOPO, RR, NPL

b. Dependent Variable: Y2

Dari uji determinasi diketahui nilai dari $\mathrm{R}$ Square adalah 0,861 yang berarti model regresi dipengaruhi $86,10 \%$ oleh variabel BOPO, RR, NPL dan sisinya dipengaruhi oleh faktor lainnya yang tidak terdapat dalam model.

\section{SIMPULAN DAN SARAN}

\section{SIMPULAN}

1. Variabel independen BOPO (X1) berpengaruh signifikan terhadap ROA (Y1)

2. Variabel independen NPL (X2) tidak berpengaruh sinifikan terhadap ROA (Y1)

3. Variabel independen RR (X3) berpengaruh signifikan terhadap ROA (Y1)

4. Variabel independen BOPO (X1) tidak berpengaruh signifikan terhadap ROE (Y2)

5. Variabel independen NPL (X2) tidak berpengaruh sinifikan terhadap ROE (Y2)

6. Variabel independen RR (X3) berpengaruh signifikan terhadap RO2 (Y2)

7. Secara simultan variabel BOPO (X1), NPL (X2), RR (X3) berpengaruh siginifikan baik terhadap ROA (Y1) maupun terhadap ROE (Y2).

\section{SARAN}

1. Dari deskriptif data diketahui nilai rata-rata BOPO dari 24 sampel adalah $86,1478 \%$ hal ini menunjukkan biaya operasional terhadap pendaptan operasional perbankan yang yang menjadi sampel masih sangat tinggi. Bank perlu melakukan efisiensi biaya dalam dalam aktivitas opersinya.

2. Rata-rata non performing loan (NPL) adalah $2,6022 \%$ walaupun masih dalam batas wajar atau ketentuan regulator yaitu 5\%, perlu dikelola dengan baik dan hati-hati karena tetap berpengaruh kepada pendapatan bank.

3. Rata-rata giro wajib minimum (reserve requirement/RR) dalah $7,7611 \%$, sebaiknya juga disesuaikan dengan ketentuan regulator, karena bilamana melampaui batas yang ditetapkan akan berpengaruh kepada jumlah aktiva produktif dan pada akhirnya berpengaruh terhadap pendapatan bank. 


\section{National Conference of Creative Industry: \\ Sustainable Tourism Industry for Economic Development}

Universitas Bunda Mulia, Jakarta, 5-6 September 2018

ISSN No: 2622 - 7436

\section{DAFTAR PUSTAKA}

Abiola I. dan Olausi, A.S. The impact of Credit Risk Management on the Commercial Banks Performance in Nigeria. International Journal of Business and Management. 2014.

Alshatti, Ali Suleiman. The Effect of Credit Risk Management on Financial Performance of the Jordanian Commercial Banks. Investment Management and Financial Innovations. Vol 12. Issue I. 2015

Aruwa, S.A. dan Musa, O.A. Risk components and the financial performance of deposit money in Nigeria. International Journal of Social Science and Entrepreneurship. 2014.

Gestel, T.V dan Baesens, B. Credit Risk Management Basic Concepts Financial Risk components, rating analysis, models, economic and regulatory capital. Oxford University Press. 2008.

Hosna, A., Manzura, B. dan Juanjuan S. credit risk management and profitability in commercial banks in Sweden, Master Theses. 2009.

Hull, John C. Risk Management and Financial Institutions. Pearson Education Inc. New Jersey. 2007

Kolapo T.F., Ayeni R.K., dan Oke M.O. Credit risk and commercial banks' performance in Nigeria: a Panel Model Approach. Australian Journal of Business and Management Research. 2012.

Musyoki D. dan Kadubo A.S. The Impact of credit risk management on the financial performance of banks in Kenya for the period 2000-2006. International Journal of Business and Public Management. 2012.

Nawaz, M. dan Munir, S. Credit risk and the performance of Nigerian. Interdisciplinary Journal of Contemporary Research. 2012.

Ogboi Ch dan Unuafe, O.K. Impact of the credit risk management and Capital adequacy on the financial performance of the commercial banks in Nigeria. Journal of Emerging Issues in Economic, Finance and Banking. 2013.

Poudel, R.P. The impact of credit risk management on financial performance of commercial banks in Nepal. International Journal Arts and Commerce. 2012.

Singh, A. Credit Risk Management in Indian Commercial Banks. International Journal of Marketing, Financial Services and Management Research. 2013.

Website:

Bank Indonesia. www.bi.go.id, situs resmi dari bank sample. 